\title{
ECONOMIC Aspects of Agricultural AND FoOd BioseCURity
}

\author{
David A. Hennessy
}

Concerns about biosecurity in the food system raise a variety of issues about how the system is presently organized, why it might be vulnerable, what we could reasonably do to better secure it, and the costs of doing so. Emphasizing the role of incentives in efficient resource allocation, this article considers economic dimensions of three aspects of the general problem. One is the global problem, or the way biosecurity measures can affect how countries relate to each other and the global consequences that result. Another is how to best manage the immediate aftermath of a realized threat in order to minimize damage. The third is how to seek to prevent realization of the threat. Some policy alternatives are presented.

$\mathrm{T}$ HE ECONOMIC DIMENSIONS OF agricultural and food biosecurity cannot be ignored. The online dictionary Encarta ${ }^{\circledR}$ defines biosecurity as "the protection of the economy, environment, and health of living things from diseases, pests, and bioterrorism." Robbins defined economics as the inquiry into "choices made by individuals and societies concerning alternative uses of scarce resources employed to satisfy unlimited wants."1(p15) Efforts to provide security, whether by governments or firms, inevitably consume scarce resources. In 2006, actual U.S. government spending on civilian biodefense amounted to $\$ 5.374$ billion. ${ }^{2}$ Of this, $\$ 0.259$ billion (4.8\%) was spent by the U.S. Department of Agriculture (USDA). ${ }^{2}$ Estimates of private expenditures in the sector are unknown but are likely to be large, since production in food and agriculture is overwhelmingly concentrated in private sector firms.

To those with malevolent intent, the food system is a plum prize. It is biological, offering opportunities to trick the target into growing the noxious agent. Food is consumed, providing a direct delivery mechanism. Food has cultural resonance in that it helps to distinguish a society and is usually consumed in the seeming security of one's own home. A significant failure in the food system can undermine a population's confidence in its government and institutions in ways few other disruptions can. In addition, the food system is in some ways particularly vulnerable to natural breakdown and deliberate attack. (Others have elaborated on this, ${ }^{3,4}$ and I will mention vulnerabilities only when relevant to other discussions.)

In the United States, where the threat is perhaps most real, federal, state, and local governments have responded since 2001 through legislation, regulatory actions, resource reallocations, and the formulation of contingency plans. 5,6 Less is known about autonomous responses by private firms, although the melamine pet food scare of 2007 points to the continuing need for strong firm-level incentives to carefully scrutinize all facets of feed and food production.

In at least one relevant sense, Robbins's definition is insufficiently articulate, and this is especially so when the matter is biosecurity. Biosecurity is provided at many levels, and decisions are made with diverse objectives in mind. Centralized decision making on biosecurity in agriculture, a very decentralized sector, is not possible. Any attempt to understand and encourage appropriate biosecurity choices must address these divergent incentives.

For example, the objectives of different governments need not be consistent when it comes to biosecurity. Regions differ in regard to endemic diseases and pests. Con- 
sumers differ in the nature and strength of demands for food quality and safety. Societies differ in perceived vulnerabilities. In addition, exporting countries may view certain importer biosecurity requirements as trade protectionism. The objectives of heterogeneous producers will also differ. Activities on a farm have biosecurity consequences for other farms. Infectious diseases spread spatially from farms where misfortune and/or lapses in defense have allowed entry. A farm may have insufficient incentive to incur a cost it bears in full in order to provide a benefit it shares only in part. Thus, the government may find it necessary to, as best it can, promote biosecurity.

Whatever the origin and technical attributes of a biosecurity problem, government policy should seek to guide resources so as to minimize the expected overall cost to society. The intent of this article is to discuss the role of economic concepts for agricultural and food biosecurity in the United States. In doing so, particular emphasis will be placed on economic incentives and on the nature of some economic costs associated with different biosecurity measures. Five key ideas are emphasized and followed through in policy discussions: comparative advantage, externality, public good, incentives, and scale economies.

The remainder of this article has seven main parts. The first briefly provides some facts about U.S. food production and biosecurity. The second deals with global dimensions of agricultural biosecurity, including how trade and biosecurity interact, as well as incentive failures that motivate international agreements to limit economic harm. In the third part, aspects of response strategies in the event of a threat realization are considered. The next section steps back to ask what could be done to prevent the crisis. Then, a case study of Asian Soybean Rust is provided. A classification of government policies by realm of activity and by purpose is provided and discussed. Finally, some policy suggestions are presented.

\section{SOME Facts about U.S. FoOD PRODUCTION}

While on-farm agriculture (i.e., viewed narrowly) accounted for about $0.8 \%$ of U.S. Gross Domestic Product

Table 1. Farm Level Cash Receipts by Commodity in the United States, 2005

\begin{tabular}{lcc}
\hline Commodity & $\begin{array}{c}\text { Value of Receipts, } \\
\text { in \$ Billion }\end{array}$ & $\begin{array}{c}\text { \% of Total } \\
\text { Receipts }\end{array}$ \\
\hline All commodities & 239 & 100.0 \\
Livestock and products & 125 & 52.3 \\
Crops & 114 & 47.7 \\
\hline
\end{tabular}

Source: U.S. National Agricultural Statistics Service. ${ }^{8}$
Table 2. United States Agricultural Exports, 2005

\begin{tabular}{lc}
\hline Product & $\$$ Billions \\
\hline Red meats \& products & 4.3 \\
Poultry meats \& products & 3.0 \\
Wheat & 4.3 \\
Corn & 4.8 \\
Soybeans & 6.3 \\
Fruits, nuts, etc. & 6.4 \\
Vegetables \& products & 5.8 \\
Cotton & 4.0 \\
Total, incl. other ag. exports & 63.0 \\
\hline
\end{tabular}

Source: U.S. Agricultural Trade Update, Economic Research Service, USDA, February 13, 2007. http://usda.mannlib.cornell.edu/MannUsda/ viewDocumentInfo.do?documentID=1412. Accessed January 23, 2008.

(GDP) in 2005, the share of U.S. GDP spent on food was $9.8 \%$ in that year. ${ }^{7 *}$ Table 1 lists market receipts for the U.S. livestock and crop sectors, and Table 2 lists revenues from some of the main exports. Because the U.S. is a large geographic area, it is more diverse in its agricultural outputs than most countries. Farm-level receipts when averaged over the U.S. population amount to about $\$ 800$ per person.

Crops and livestock account for approximately equal revenue shares in the U.S., but bovines (meat animals and also milk) account for $31.8 \%$ of receipts, while broilers account for a further $8.1 \%{ }^{8}$ By contrast, crop receipts are spread over a wide array of products. Plant sector vulnerabilities are discussed in detail by Fletcher and colleagues, who comment on the ease of acquiring, cultivating, transporting, and disseminating a plant disease. ${ }^{9}$ On the whole, as the comparative levels of attention provided by analysts suggest, animals and poultry seem to be more vulnerable targets. ${ }^{3,5}$ This is in part because the affected animals move, are more valuable, and can be difficult to clear of disease. Destroying a large number of animals is emotionally stressful for all concerned, and avian influenza and other zoonotic diseases present concerns for human health. In addition, indoor production on a large scale allows for rapid spread of an infectious agent within a given herd. ${ }^{\dagger}$

Attribution of U.S. federal and state expenditures to agricultural and food biosecurity is difficult because many of

*GDP, product sales, and other commonly used measures of economic contributions are not good measures of true contribution. Water and air are essential for life, but make small contributions to the GDP measure. Data for better measures are generally too costly to obtain.

${ }^{\dagger}$ A proper accounting for economic losses to an economy from endemic animal and crop diseases is difficult because one has, for example, to include prevention costs. Supplemental materials detailing loss sources and problems measuring these losses are available upon request from the author. 
these outlays are general purpose. Monke reports federal accounting categories when itemizing expenditures. ${ }^{10}$ In 2006, a total of $\$ 861$ million was spent, much of it on capital investments. Of this, $\$ 446$ million was spent on border and transportation security, and a further $\$ 114$ million was dedicated to protecting critical infrastructure. In recent years, a major use of funds in this category was for building a veterinary laboratory in Ames, Iowa. Appropriations for defense against catastrophic threats amounted to $\$ 238$ million, with a large fraction of this going to the Animal and Plant Health Inspection Service (APHIS) for monitoring, surveillance, and laboratories that facilitate response capabilities. Only $\$ 5.2$ million was spent on intelligence, because most spending in the area is not dedicated to agriculture. Clearly, such data are of limited utility in planning as they are formed more by accounting procedures than by the information content for planners seeking to allocate funds efficiently.

\section{Global Problems}

In this section, I discuss two themes regarding international dimensions of agricultural biosecurity. One is trade, which can be adversely affected by biosecurity measures, and the other is that biosecurity is often what is referred to as a "public good." At the country level of analysis, a public good is best provided at the international level.

\section{International Trade}

Food export markets are important for many countries, including some that are developed and heavily urban. Several recent articles have provided perspectives on how hoof-andmouth disease (HMD) has affected production in Taiwan and the United Kingdom over the past decade. ${ }^{1-15}$ Why is such emphasis placed on maintaining access to international markets? The theory of comparative advantage in international trade is the idea that two countries can benefit from trading goods even if one country has an absolute advantage in producing both goods. Trade allows for gains from specialization in our diverse capabilities, rather than leaving resources idle, and comparative advantage determines the direction of trade. Trade can allow for more outputs from the same level of world resources. Trade in agriculture and food is largely motivated by the role of climate in plant growth.

The theory comes, however, with important qualifications. Among these is the absence of what are known as negative externalities. These are costs that someone imposes on someone else-that is, people do not bear all consequences of their actions. Infectious disease is a classic illustration of a negative externality, and so there can be grounds for imposing trade restrictions. There also can be grounds for better preparing countries for some adverse consequences of increasing openness, and many are concerned that this is not happening. ${ }^{4}$ For instance, while a country as a whole may gain from trade, some interest groups may lose. The possibility of trade restrictions due to concerns about infectious animal and plant disease, therefore, provides groups with an opportunity to renegotiate a market environment. Although the politics are often appealing, the economic consequences of widespread renegotiations of this sort would likely be very negative in the long run.

In summary, attempts to address vulnerabilities at the border provide strong international dimensions to biosecurity problems. Possible responses include tackling problems at their source, trying to restrict movements of goods and people, and monitoring borders for suspicious traffic. It is the preponderant view among economists that potential losses would have to be very large before tight restrictions on the movements of goods and people would be the most appropriate action.

\section{The Public Good}

How then can international commerce be promoted while safely guarding a country from biosecurity breaches? Many of the institutions in place for doing so are founded on the concept of a public good. A public good is one that has two defining attributes: (1) it can be used by more than one consumer without unduly compromising its utility to other consumers, and (2) it is difficult to exclude potential users. ${ }^{16} \mathrm{~A}$ food item is not a public good because only one person can consume it. Except for heavily used roads, where congestion is frequent and tolling infrastructure may be possible, a road is generally viewed as a public good. Private citizens who spend money on public goods cannot exclude in order to charge other users for access and so recoup their investment. So private individuals do not have strong profit incentives to make public good investments, and public goods are often best provided by governments. Many goods that provide security are public in nature. A police force may be able to efficiently secure all citizens and property in a town, while the law prohibits deliberate exclusion. At the international level, biosecurity may often be considered to be a public good. If a communicable disease problem is eliminated in one country, then all other countries gain in this globalized age. To some extent, security from terrorism is an international public good, as many terrorists target multiple countries.

Through some of its units, the United Nations seeks to control infectious animal diseases at the transnational level. Separately, the World Organization for Animal Health (or OIE) is dedicated to addressing public good aspects of global animal disease problems. For many low- and middleincome countries, animal agriculture is comparatively im-

Biosecurity and Bioterrorism: Biodefense Strategy, Practice, and Science 
portant, very limited veterinary resources are available, and national governance structures are weak. OIE efforts include information transfer, coordination activities, and endeavors to provide continuity in animal disease management efforts. These and related infrastructure may assume greater importance in the future if regulations and labor costs hasten the exit of animal production from developed countries.

Is it wasteful for several transnational entities to address infectious agricultural disease problems in less developed countries? Probably not. These entities often have different goals and approaches. Developed and developing countries differ in ways that matter for the spread of disease. Apart from differing consumption preferences, healthcare infrastructure, and production practices, the climate tends to be more temperate and fewer wildlife reservoirs remain in developed countries. Diseases that concern developed countries are not necessarily those most damaging to developing countries. A single entity trying to meet all the goals of recipient and donor countries might devote too much attention to reconciling conflicting objectives.

\section{RESPONSES}

Rapid mobilization of resources during a crisis can be challenging for a free society. Often, resources have to be coaxed free while urgent decisions must be made about trade-offs between individual rights and the social good. In the case of animal and crop diseases outbreaks, the sacrifices to be made may jeopardize a business's capacity to survive. In addition, the typically growing share of nonfarmers in a rural community will be asked to forbear for a sector that has developed image problems of various hues. This section deals with some issues on response in crisis that are distinctive to rural locations and agricultural/food markets.

\section{Production Structure}

Table 3 indicates that agricultural ownership structures are increasingly concentrated in the U.S. ${ }^{\ddagger}$ Poultry and feedlot beef production have long been large scale, and this is now also true of hog and dairy production. In 2004, hog operations with inventory exceeding 5,000 animals accounted for $53 \%$ of U.S. hog inventory but $1.6 \%$ of all producers. ${ }^{8}$ Of 938 million U.S. farmland acres in 2002, 353 million were rented or leased. ${ }^{18}$ In Iowa, $20 \%$ of farmland was owned by someone not living in the state, while $46 \%$ of Iowa farmland was operator-owned in 2002. ${ }^{19}$ Environmental problems are changing how farming and nonfarm-

‡Rushton and Upton provide more detail on rural demography and animal sector structure as they relate to biological emergencies. ${ }^{17}$
Table 3. Number of Farms in the United States, by Enterprise

\begin{tabular}{lrr}
\hline $\begin{array}{l}\text { Enterprises engaged } \\
\text { in }\end{array}$ & 1974 & 2002 \\
\hline Beef cows & 1,025 & 796 \\
Dairy cows & 404 & 92 \\
Hogs & 470 & 79 \\
Broilers & 34 & 32 \\
Grain corn & 883 & 349 \\
Wheat & 534 & 170 \\
Soybeans & 542 & 318
\end{tabular}

Source: U.S. Department of Agriculture. Census of Agriculture. http://www.agcensus.usda.gov/. Accessed January 23, 2008.

ing neighbors view each other and may decrease tolerance for inconveniences that will arise in attempts to control a disease outbreak.

\section{Information Systems and Animal Identification}

Response to infectious disease is a classic case of a public good, and a role for government is indisputable. Production animals are often moved to better utilize comparative advantages in feed and management. Recent disruptive animal disease events have convinced many in developed world animal agriculture industries of the pressing need for better animal tracing capacity. Tracing should facilitate control of a problem as it arises and also provide a better understanding of the problem in retrospect. Tracing capacity should be as far-reaching as is practicable and should certainly include premises registration. European Union (EU) regulation 820/97 requires identification and tracing capabilities for EU bovines and bovine products. EU countries share movement information, and many EU countries have developed geographic information systems to use this information. ${ }^{20}$

The U.S. has instituted a voluntary National Animal Identification System (NAIS) that includes premises registration, animal identification, and tracing capacity. Whether the NAIS that emerges is well-coordinated must be a concern. Diverse databases may require costly human intervention during a crisis. By contrast with the EU, where commodity tracing has been mandated, the U.S. has less leverage with animal producers. This is because the U.S. animal agriculture sector has generally not received government payments that are significant in proportion to their income. Conditioning the payments that do occur on behavior may not meaningfully change farm-level actions.

For a variety of reasons, not all farmers have wished to join the NAIS. For instance, incentives may not be strong because the private cost of joining is incident on the given farm but the benefits are shared by many, including people not involved in the agriculture and food sectors. Many pro- 
ducer organizations have, however, been very supportive of premises registration and the NAIS in general. Private sector identification systems are also expanding because of increasing demand for product and source verification and because of growth in contract-based agricultural production. The U.S. sheep sector already has a template identification system in place. This arose from mandatory federal regulations to identify breeding animals for the National Scrapie Eradication Program, which commenced in 2001.

\section{Preparation for Response}

Perhaps the most important issue regarding preparedness for an animal-related biosecurity failure is where veterinary personnel would come from. ${ }^{3}$ The U.S. veterinary medicine profession is increasingly nonagricultural, with fewer than 10,000 private practitioners significantly involved in animal agriculture. ${ }^{21}$ Animal sector intensification and the declining real dollar value of animals have been responsible for reduced farm demand for veterinary services. These trends are likely to continue, although perhaps modified by the rise in organic and other alternative farming models. Veterinary services at larger farms increasingly deal with herd health. Industrial-format production simplifies preparation for response because identifying and processing the majority of animals will be easier when responding to an outbreak.

Nonetheless, the declining number of veterinary professionals serving agriculture has been a concern in the U.S. The U.S. National Animal Health Emergency Response Corps, initiated in early 2001, is a roster of volunteers that can be quickly mobilized and has been called up on several occasions. Call-up is handled by the U.S. Department of Agriculture APHIS division, who pay food and lodging expenses. Concerning longer-term preparations, loan subsidies to veterinary students who declare their intent to enter a food animal-focused career are now available through funding authorized under the U.S. National Veterinary Medical Service Act of 2003.

\section{Continuity of Business}

Except for some branded food items, agricultural production and processing are low-margin businesses on the whole. In many cases, firms must be able to accommodate dramatic temporary price downturns, and temporary shutdowns are one way of doing so. Historically, the labor-intensive nature of agriculture provided flexibility in coping as other crops were grown or workers were laid off. Increasingly, though, dedicated capital and sustained marketing efforts are needed to penetrate premium markets where expectations of food quality and safety are high. Adequate returns on these sunk investments require reliable markets.

Biosecurity failures that result in market foreclosure over indefinite periods can lead firms to respond by giving up on seeking to re-enter international markets. Taiwanese pork and Guatemalan raspberry sectors have faced these problems over the past decade, to name but two well-known cases. ${ }^{15,22}$ Less visibly, firms may decide not to invest in the first place if they expect such business disruptions to be costly and sufficiently probable. Private sector insurance to cover these events is unlikely to be effective, even if it is available, because coverage will almost certainly be over a short period and probably will not include price discounts arising from damaged reputation after any eventual market re-entry.

\section{PREVENTION}

Prevention involves making resource allocation choices about low probability risks that may materialize in the indefinite future. People are not particularly good at making such decisions, tending to overemphasize some risks and place too much weight on the recent past. ${ }^{23}$ These failings are systematic, applying just as well in the collective (i.e., for government decisions) as in the individual. Leaving aside concerns about deciding what to do, what follows comments on three aspects of implementing prevention strategies of particular relevance to agricultural biosecurity.

\section{Communication and Education}

Entry of an exotic infectious disease is most likely at the weakest link, spreading from there. If a costly action can be taken by each participant in the industry to reduce entry risk, participants can follow one of two strategies. They can fail to act out of the belief that they have little control over whether they are affected, or they can believe that others are likely to do their parts and view themselves as the weak link. Then each participant has strong incentives to act. It all depends on what participants think others are doing and, thus, on the information they have available about the behavior of others.

Communication is key, and this can occur through animal industry groups or through government programs. Some U.S. producer groups (e.g., poultry) have been more active in biosecurity outreach than others, perhaps because of perceived risk. Given their education outreach mission, land grant universities are appropriate places to look to for organized outreach. A cursory scan of the internet, together with informal discussions, suggests that the extent to which veterinary medicine extension personnel in the U.S. are coordinating in providing biosecurity materials could be improved on. Two questions are: Is there a centralized biosecurity website that aggregates worthy outreach materials? Have these personnel convened to discuss how they could assist in the event of a failure in biosecurity?

Biosecurity and Bioterrorism: Biodefense Strategy, Practice, and Science 
Table 4. Internal (State-to-State) Live Animals ShipmentsUnited States $^{\mathrm{a}}$

\begin{tabular}{lcc}
\hline & $\begin{array}{c}1980 \\
\text { million head } \\
\text { (\% of inventory) }\end{array}$ & $\begin{array}{c}2006 \\
\text { million head } \\
\text { (\% of inventory) }\end{array}$ \\
\hline Cattle & $20.0(18.0)$ & $21.0(21.7)$ \\
Pigs & $4.6(7.1)$ & $35.6(58.0)$ \\
Sheep & $2.2(17.3)$ & $1.5(23.6)$ \\
\hline
\end{tabular}

Source: U.S. Department of Agriculture. Statistics Service. http://www. nass.usda.gov/Data and Statistics/Quick Stats/index.asp. Accessed January 23, 2008.

aPercent of annual inventory data are in parentheses. Cattle inventory percent is for January 1 inventory of all cattle and calves. Pig inventory percent is for December 1 inventory of all hogs and pigs. Sheep inventory percent is for January inventory of all sheep and lambs.

\section{Scale and Trading}

Within a country, disease problems may be due to incentive problems arising from industry structure. Business people may organize firms in part as an attempt to overcome incentive problems regarding disease transmission. Consider that cattle production has generally lagged behind pig and poultry production in biosecurity measures taken. Cattle farms throughout much of the world also tend to be more reliant on purchased animal inputs than are (typically larger-scale) pig and poultry operations. This may, in some measure, be due to older age of the animals at slaughter. Comparative advantage also plays a role as trades are motivated by changing dietary needs during grow-out and finding markets for surplus dairy calves. Transferring young animals through sales auctions, rather than by contract or ownership from suckler herd to finish, often predominates. Imperfect downstream information on animal history then rationalizes private upstream decisions to avoid biosecurity costs. Biosecurity problems will be less severe if downstream farms have reliable knowledge about the source of their animals. ${ }^{24}$

Tables 4 and 5 show that there are growing internal and international shipments of nonruminant live animals, fed mainly on internationally traded grains. Public data on trading and movement activities within the U.S. are sparse. Whether the extent of movement should be a worry depends very much on how these animals are traded and subsequently managed. Available evidence suggests that larger feedlots tend to be more careful about the animals they buy and to have better biosecurity programs in place for introduced animals, thus at least partly offsetting their greater level of exposure.

Table 6 provides circumstantial evidence for evaluation of performance across farms at different scale levels in U.S. dairying. It summarizes data from the Agricultural Resource Management Survey (ARMS) in 2000. ${ }^{26}$ Productivity differentials are marked for both output level and input use efficiency. Declining input use per unit output as output increases shows that there are scale economies to be ob- tained in labor and feed costs. Organic (both small-scale and large-scale) and other production formats are growing and promise to be relevant components of agricultural production in the future. ${ }^{27}$ However, cost data suggest that industrial format production will continue to expand absent regulatory intervention. In many low-income countries, large animal farms are emerging. ${ }^{28}$ The trend toward scale has come with a closing off of animal production systems. Accompanying features are emphasis on control, more formal information and information management, and more automation. Many biosecurity investments involve scale economies, whether capital investments or through specialized labor. To illustrate, consider a perimeter fence around a square production facility where the fence costs $\$ 10 /$ meter. With one animal per square meter the cost is $\$ 40$ per animal, but it is $\$ 0.4$ per animal for 10,000 animals.

Agricultural structure is an emotional topic, and care is required if objectivity is to be retained. The debate on biosecurity and production structure needs to be considered on its own merits before including this dimension in the larger picture. Vertical integration (i.e., integrating from farm-to-fork) often does entail transportation during an animal's growth. But many economies from vertical integration are due to a rationalized supply chain that involves fewer relocations, fewer trips to sales barns, and more closely monitored transportation. The higher-performing animals that typically exist on integrated farms may be more vulnerable to immune system shocks. Horizontal integration (i.e., larger feedlots) does involve larger losses if a risk materializes but also motivates greater care that the loss does not materialize. Larger farms should also be easier to integrate into an emergency preparation and response system, perhaps with internet connections. There is a dearth of research on how production structure and behavioral response to this structure affect biosecurity risks.

\section{Zoning and Other Land Policies}

Land use externalities have long been recognized in land zoning policy formation. The provision of services to residential, commercial, industrial, and agricultural properties is cheapest when similar properties are clustered. Safety and nuisance externalities are minimized when space separates

Table 5. Worldwide Exports of Live Animals (million head)

\begin{tabular}{lrr}
\hline Item & 1981 & 2004 \\
\hline Cattle & 7.3 & 8.0 \\
Pigs & 9.6 & 22.7 \\
Sheep & 15.8 & 14.8 \\
Chickens & 366.2 & 816.9 \\
Turkeys & 14.6 & 64.0
\end{tabular}

Source: Food and Agriculture Organization, Agricultural Data, Agricultur and Food Trade, various issues. http://faostat.fao.org/site/342/ default.aspx. Accessed January 23, 2008. 
Table 6. Summary of ARMS 2000 Dairy Survey Data

\begin{tabular}{lccc}
\hline & \multicolumn{2}{c}{ Enterprise Size (Cows) } \\
\cline { 2 - 4 } Summary statistic (all are averages) & $\begin{array}{c}\text { Medium } \\
50-99\end{array}$ & $\begin{array}{c}\text { Large } \\
100-499\end{array}$ \\
\hline Herd size & 88 & 313 & 955 \\
Output/cow (lb./year) & 16,157 & 17,420 & 17,326 \\
Labor efficiency (hours/100 lb. milk) & 0.44 & 0.19 & 0.11 \\
Feed efficiency (lb. feed/100 lb. milk) & 252 & 317 & 162 \\
Veterinary expenses $(\$ / 100 \mathrm{lb}$ milk) & 0.71 & 0.58 & 0.60 \\
\hline
\end{tabular}

Note: Data are as reported in tables 4 and 5 of Short. ${ }^{25}$

dissimilar properties. Spatial woodland policy often emphasizes variety, wildlife, and firebreaks. Proximity contributes to disease spread: congested hog production was considered to be a factor in Taiwan's HMD outbreaks a decade ago. ${ }^{11}$ The mixing of species — pigs and poultry or fish species, for example-and use of communal land for grazing are also known to feature in the introduction and spread of a disease. The appropriate role for government in managing these externalities depends not only on the nature of the most likely infections but also on the effectiveness of veterinary health infrastructure, incentives facing producers, and actions available to producers.

\section{Case Study: Asian Soybean Rust}

Although animal diseases are widely considered to be the main sources of biosecurity risk, ${ }^{3}$ plant crops also are vulnerable. ${ }^{9}$ Asian soybean rust (ASR), a fungal disease usually caused by Phakopsora pachyrhizi, was first identified in the continental United States in November $2004 .{ }^{29}$ It is likely that spores were blown across the Gulf of Mexico during a hurricane. Versatile in overwintering on a wide variety of plants along the U.S. Gulf Coast, it has the potential to cause great damage to soybean growers. It often halves crop yields in Asia, Africa, and South America. ${ }^{30}$

In anticipation of what had been considered to be practically inevitable, during early 2004 the USDA drew up a strategic plan for protection, detection, response, and recovery. ${ }^{31}$ By May 2005, the department had made public a coordinated framework for controlling the pest. ${ }^{32}$ Previously considered to be a select agent under the U.S. Agricultural Bioterrorism Protection Act of 2002, ASR was removed in March 2005 in order to promote further study, as it was expected to become endemic in the U.S. The primary goals of the strategic plan and coordination framework have been to guard against the annual spread of spores from the Gulf Coast into the main soybean growing areas, as well as to develop short- and long-run strategies for managing infection.
Emphasizing federal, state, and private sector involvement, the plan employs surveillance, prediction modeling, internet-based information management and communication, and evolving fungicide application recommendations to growers. An important, and implemented, component of the plan is the sentinel plot network that extends through all relevant areas of the U.S. Perhaps because of fortunate weather realizations, disease losses in the U.S. have not been large through to the 2007 crop year.

Deliberate distribution, perhaps motivated by the intent to gain financially, is a concern. In the unlikely month of March 2007, one ASR-infected leaf was presented for identification to the Iowa State University Plant Disease Clinic. It was asserted to have been found in a grain bin on an Iowa farm. ${ }^{33}$ Despite extensive investigations at and near this site, no further infections were found at that time, or indeed anywhere in the upper corn belt, until late in September of that year. Echoing sentiments of plant pathologists, the Iowa Secretary of Agriculture asserted, "If it was represented to come from a field it did not come from, then it is doubtful it was a mistake." 33

The rust demonstrates how important several characterizing features of agricultural production can be to biosecurity. In production systems so open to nature, even the best forensic science often cannot definitively establish whether an introduction was intentional. This openness also can make eradication vexingly difficult, perhaps especially so for plant agriculture. Government involvement generally is necessary, as surveillance and other approaches to control amount to a public good. In addition, individual growers lack sufficiently strong pecuniary incentives to take actions that are available to them. Meaningfully engaging the private sector to facilitate public efforts at control is essential, and incentives must be in place for this to occur.

\section{Policy Classification}

Although largely modest and not intrusive, government involvement in promoting biosecurity is extensive through-

Biosecurity and Bioterrorism: Biodefense Strategy, Practice, and Science 
out the agriculture and food sector. It is often difficult to attribute a government activity to a particular end because many government activities are general in purpose, to be used for a variety of contingencies. Following the National Research Council, activities may be viewed under (1) deterrence and prevention, (2) detection and response, and (3) recovery and management. ${ }^{34}$ Table 7 places a classification on the primary functions of government activities within this rubric.

The classification is inevitably crude since the reach and breadth of government in all its forms ensures that any broadly defined set of government activities furthers all of prevention, detection, and recovery, at least to some extent. Three categories are listed under the broad heading of "Transnational." International cooperation, through bilateral agreements and aid or through such global institutions as United Nations organizations and the OIE, should reduce the extent of external biosecurity problems. While largely intended to promote detection, border activities will increase the cost of supplying unsafe or suspect goods to a country and so should deter the presentation of such goods at a country's borders. Well-functioning phytosanitary protocols in trade agreements should also screen out such goods, while timely resumption of trade after a problem has been addressed should provide a sector with the resources and incentives to recover.

Acquiring and sharing of information by the general intelligence agencies of a country and its allies should aid in deterrence and detection. Recovery, too, should be promoted by clarifying who was responsible for any deliberate security breach. Within a country, the National Animal Identification System, plant sentinel plot networks, and national disease laboratories ought to provide information necessary for response as well as data to analyze how best to prevent further problems. Governments may find it necessary to alter incentives for protecting food during production, distribution, and retail, even though this may be limited in effectiveness. This might include mandates or subsidies to prevent through biosecurity actions, to report problems, and to alter production practices during the recovery process.

Governments have become involved in animal and plant protection markets in a variety of ways. Antibiotic use in agriculture-and especially in animal production, where the practice is more prevalent-has raised concerns about the rate at which resistant bugs emerge to attack humans. Vaccine markets have long been problematic because demand is sporadic, there are production lags, the strain produced may not be effective, and producers may feel vulnerable to a government that often sets the price when it is a major consumer. The U.S. Homeland Security Presidential Directive 9 (HSPD-9) authorized the National Veterinary Stockpile in order to have animal vaccines, antivirals, and therapeutic products available for rapid response to critical animal disease problems.

Throughout the world, involvement by government in vocational training and education markets is extensive. The motive has often been for equity considerations and to promote talent rather than to guide vocational outputs. Private demands for biosecurity skills will likely grow, but these demands may be tilted toward skills that better protect a given firm's reputation and bottom line. Needs for skills that generate public good, such as epidemiology, may not be met without public support. Turning to finance, insurance markets, like vaccine markets, for animal disease and other biosecurity events have not functioned well in the past. But

Table 7. Classifying Government Agricultural Biosecurity Activities by Purpose

\begin{tabular}{|c|c|c|c|c|}
\hline Category & Purpose & $\begin{array}{l}\text { Deter \& } \\
\text { Prevent }\end{array}$ & $\begin{array}{l}\text { Detect \& } \\
\text { Respond }\end{array}$ & $\begin{array}{l}\text { Recover \& } \\
\text { Manage }\end{array}$ \\
\hline Transnational & $\begin{array}{l}\text { International cooperation } \\
\text { Border activities } \\
\text { Trade agreements }\end{array}$ & $\begin{array}{l}X \\
X \\
X\end{array}$ & $\mathrm{X}$ & $\mathrm{X}$ \\
\hline Information & $\begin{array}{l}\text { General information gathering \& sharing } \\
\text { NAIS \& plant disease detection system } \\
\text { Animal \& plant diagnostic laboratories }\end{array}$ & $\mathrm{X}$ & $\begin{array}{l}X \\
X \\
X\end{array}$ & $\begin{array}{l}X \\
X \\
X\end{array}$ \\
\hline $\begin{array}{l}\text { Markets \& } \\
\text { Incentives }\end{array}$ & $\begin{array}{l}\text { Farm, factory, retail protection } \\
\text { Animal \& plant protection markets } \\
\text { Markets in training \& education } \\
\text { Financial \& insurance markets }\end{array}$ & $\begin{array}{l}\mathrm{X} \\
\mathrm{X}\end{array}$ & $\begin{array}{l}X \\
X \\
X \\
X\end{array}$ & $\begin{array}{l}X \\
X \\
X \\
X\end{array}$ \\
\hline $\begin{array}{l}\text { Other } \\
\text { General } \\
\text { Public } \\
\text { Infrastructure }\end{array}$ & $\begin{array}{l}\text { Legal framework \& government fiat } \\
\text { Civic defense infrastructure } \\
\text { Technical services, including extension } \\
\text { Substance control, including fertilizers }\end{array}$ & $\begin{array}{l}X \\
X \\
X\end{array}$ & $\begin{array}{l}X \\
X \\
X\end{array}$ & $\begin{array}{l}X \\
X \\
X\end{array}$ \\
\hline
\end{tabular}


a degree of financial stability is necessary if a sector is to recover from a crisis. This is because firms with an uncertain future are unlikely to make the long-term commitments that may be necessary to shield the sector from similar problems in the future. Even firms that have the resources to weather the event may not make the investments. They may rely on a local processor or other infrastructure to continue in business and have trepidations that too few producers will survive to support the infrastructure.

While a crisis often demands that a government move quickly, state laws may limit the extent to which this can occur. Such was the case with Asiatic citrus canker (Xanthomonas axonopodis) in Florida, where it has spread since reintroduction, probably in the mid-1990s. ${ }^{35}$ In November 2000 , property owners obtained an injunction against having their trees felled. It took 18 months and passage of a new state law before the eradication program resumed, and even then it faced further legal challenges. But by then pathogen infection had become extensive in south Florida.

Governments provide technical services through bundling information on regulations with suggestions on compliance. In the U.S., land grant universities are charged with developing new technologies to address a state's problems and also with informing interested parties on how best to address the problems. The deliberative, sometimes ponderous, nature of academic inquiry and of bureaucratic processes elsewhere in government may leave slender opportunities for involvement by many government entities during a crisis, except as a source of expertise on the state of technical knowledge.

One final role for government intervention is in substance control, where agriculture and food producers have need for multiple-use chemicals. Ammonium nitrate is a popular fertilizer, but it can readily be turned into an explosive. Pending U.S. federal legislation, titled the Secure Handling of Ammonium Nitrate Act of 2007, seeks to put in place an information and reporting system that identifies and traces thefts of the chemical. Due to scale economies in compliance, such regulations may place smaller farmers at a competitive disadvantage.

\section{Policy Alternatives}

The following is a set of suggested policy alternatives. They are loosely sequenced by theme but are otherwise not ordered, and no firm sense of the dollar equivalent merits of these alternatives is provided. Omitted are any suggestions concerning the design of infrastructure, because I am far from fully apprised on how elaborate prevention and control systems are meant to work in the U.S. or elsewhere.

1. Further subsidize activities intended to reduce the prevalence of worrisome infectious animal and plant diseases in poorer near-abroad countries. Governments of developed countries are involved in such activities through diverse channels, but the task of assessing donor country benefits from such international transfers is difficult. Among the challenges are data limitations, the breadth of consequences a disease can have, scientific uncertainty, and uncertainty about the efficacy of local institutions. The magnitude of gaps between performance indicators in poor and wealthy countries implies high expected social returns on such investments. One endeavor that the World Bank and OIE has commissioned a study on, which was to have been completed in 2007, is a Global Emergency Response Fund for Animal Epizootics and Zoonoses (GERFAE). Countries would be provided with funds to (1) compensate livestock owners who report suspicious cases of livestock disease, and (2) cover direct government costs of controlling an outbreak. If it is not already being attended to by some other mechanism, then this seems like a need that should be promptly addressed within a carefully designed mechanism. The incentives put in place should encourage mainly cases of true concern to be brought forward. ${ }^{36}$ Also, education will determine the effectiveness of these efforts because growers need to be aware of compensation and have a good sense of what to look for.

2. Increase participation, through subsidies or otherwise, in animal identification and tracking systems. The U.S. government acknowledges this need, having grant funded producer groups to encourage enrollment in the NAIS. Many animal producers and processors are also acutely aware of the need. But enrollment is not enough. A premises registration list must be updated just as voter registration lists are. The voluntary approach taken in the U.S. will require carrots as the primary approach to premises registration, animal identification, and animal tracing. The extent of ultimate coverage and quality of information provided will depend on how producers are drawn into the system. Government could use leverage arising from other programs it operates. Possible opportunities to expand participation are discussed in other points on this list. As of the end of October 2007, about 29.4\% of the estimated 1.44 million livestock farms had registered with the NAIS. But participation varies markedly across states, being close to $100 \%$ in Wisconsin while at $12.7 \%$ in Ohio. A $\$ 50$ check for re-registering every 2 years would have a maximum annual cost of $\$ 35$ million (plus administration costs) per year, while the administrative burden on growers can be minimal.

3. Encourage trading other than through sales barns, and strengthen animal transportation laws. Production animals are moved and traded in order to exploit comparative advantage in feedstuff production and management specialization, where such efficiencies can be large. Consequently, efforts to reduce movement should not be taken without careful consideration. Animals are traded by private treaty or through livestock markets, which are subject to over-

Biosecurity and Bioterrorism: Biodefense Strategy, Practice, and Science 
sight. They may move long distances while not changing ownership, as with pigs farrowed in one state but grown on contract elsewhere. Animal welfare considerations are leading many jurisdictions to revisit laws on trading and transporting animals.

The foremost concern in this area, and one well understood by the U.S. government, is the need to have better movement information, including general patterns and specific movements. Oversight at livestock marts is cursory on the whole. This is not the fault of local authorities, of overseeing veterinarians, or of anyone else; it is just the nature of marts. Respiratory and fecal contact across animal lots is almost inevitable, even when great sanitary care is taken. Costly endemic diseases and diseases of direct concern to agroterrorism prevention can be communicated by these means. Mansley and colleagues document the role sheep markets played in spreading the 2001 HMD outbreak throughout Britain and beyond. ${ }^{37}$

In many cases, there appear to be problems with incentives offered when monitoring livestock markets. Market owners should bear monitoring costs but should not be in a position to influence judgments or recommendations. Inspectors should not be paid directly by the sales barn. Governments can encourage fewer trades and less risky trading channels through user fees, encouraging source verification schemes, or facilitating online markets that avoid channeling animals through a physical location.

4. Seek to better coordinate biosecurity outreach. What other producers and processors do is important knowledge as it can alter a producer's incentives to take action. In many cases, information that others act to better secure the food system should encourage a producer to do so as well. This is likely the case when the objective is to keep a disease out of a region. Farming operations differ in many ways, including access to information on their operation's security vulnerabilities. Larger operations may have strong incentives to think about security issues, if only because they have more to lose. If heavily capital intensive, then these investments may remain idle as a disease problem is being resolved. Labor-intensive farming operations, often smaller ones, can temporarily lay off workers. Furthermore, biosecurity investments will often have a large fixed cost component, which larger farms can spread over more units of production. So, larger farms may be better positioned to make biosecurity investments, including information acquisition investments.

Smaller, hobby, and alternative agriculture farms will likely endure as significant industry components. Providing biosecurity information to these farms is important, if difficult. The U.S. federal government and the land grant university system's provision of materials appear to be quite fragmented, perhaps because few outreach personnel specialize in the issue. A centralized website that diverse recipients can link to and those supplying research and outreach materials can send to would be most useful and likely not costly to maintain.

5. Use existing andlor new regulatory infrastructure to require that feeding operations comply with certain biosecurity measures. The U.S. Clean Water Act (CWA) is administered by the Environmental Protection Agency (EPA) and by individual states. The act allows for the regulation of point-source emissions into waterways. It covers about 15,500 Confined Animal Feeding Operations (CAFOs), including their emissions of nitrogen, phosphorus, metals, and bacteria. Since 2003, these CAFOs have needed a pollutant discharge permit. At a minimum, the permit requires capacities for managing several events relevant to biosecurity. These include the operation's approach to handling dead animals, chemicals, manure, and litter. The plan's emphasis is on water and not on biosecurity.

As with water quality, the government has public good responsibilities for controlling existing and exotic infectious animal diseases. Farms have a strong interest in remaining disease-free, but incentives may be inadequate because farms may not take into account how their actions affect other farms. Fencing, access control, quarantine facilities, sanitation equipment, and disposal of potentially infectious materials are among best management practices the state might seek to encourage. The Clean Water Act would likely not be a suitable point of departure, and the EPA may not be the appropriate agency. Any federal efforts to encourage or require biosecurity practices should not be burdensome, and the government would need to have a clear understanding of the costs and benefits of any best management practices. Mandatory participation by smaller units may not be practical, even if it is politically feasible.

6. Provide subsidies for the cost of installing assets that promote on-farm biosecurity. The Environmental Quality Incentives Program (EQIP) was reauthorized in the 2002 Farm Bill as a voluntary approach to environmental conservation practices by producers. It offers technical assistance and costshare subsidies for adopting environmentally friendly practices, and priorities include reducing point source pollution emissions from CAFOs. A similar program to encourage biosecurity best management practices should be as practical to implement. Several bills that have been introduced in the U.S. Congress have sought to do so. ${ }^{10}$

7. Provide insurance to growers for major disease outbreaks, and use the insurance to promote biosecurity best management practices. Economists are often reluctant to encourage intervention in insurance markets, in part because such interventions can create or exacerbate moral hazard problems. ${ }^{37}$ Put simply, if a grower is insured, then he or she may be less inclined to protect the farm against disease entry. However, the government may feel obliged to compensate smaller producers in the event of a major disease outbreak. This is in part to encourage reporting, but it can also be in response to political pressures. In the event of a disease out- 
break, and were government compensation not provided, many farmers who did take considerable care might face bankruptcy. The disease may be very contagious, or their healthy animals may be condemned as a precautionary measure.

The strong possibility that the government would compensate may undermine prospects for a viable private insurance market. Producers may see little point in buying what they will likely receive for free, if needed. But it may be nearly impossible for a government to credibly convey that it will not intervene. In addition, insurance markets are much better at insuring isolated events (e.g., house fires, auto thefts) rather than systemic, regionwide events (e.g., floods). Insurers are very reluctant to take up poorly understood contingencies that can result in widespread losses. So, the question then is how the government can leverage its implicit commitment. Conveying to all at an early stage that compensation beyond a certain minimum level will be given only to those who participate in premises registration and comply with certain monitorable biosecurity best management practices may be one way of doing so.

8. Revisit food irradiation. There is a consensus that food irradiation may affect the nutrition content of food but that the food is safe to consume. It is permissible to irradiate meat, poultry, and some other foods in the U.S. Federal regulations require that irradiated foods be labeled, and this (together with the unfortunate name) has turned consumers off. One wonders the extent to which irradiation could be used to free up resources to better secure foods in other ways.

9. Facilitate the professionalization of biosecurity management as a career. In light of the demand for personnel in the area, schools of public health have responded by providing programs that include biosecurity as a major emphasis. Curricular materials were likely taught in other courses, and individuals may already have acquired this breadth of knowledge. However, recognition that a common body of knowledge should be relevant to the careers of a significant group of people portends more than a convenient packaging of materials. It provides a vision for a discipline, just as accountancy and engineering emerged out of the Industrial Revolution.

Graduates may form networks and societies for career promotion, continuing education, and accreditation. Hiring firms are provided with the view that the biosecurity function merits specialization. A more coherent and informed demand for technical improvements in the area can lead to new products and product adaptations as well as more clearly articulated demands for research. The public sector has a role in this as it will need many biosecurity professionals in coming years. At the state level, public universities decide what majors and minors are taught. For the U.S., where professionalization of the remit seems to be underway, one way to promote the trend is to give separate ti- tles to biosecurity aspects of legislation and regulations so that firms see how others view the issue.

10. Encourage developments in economic epidemiology. A variety of policy topics in recent years, including invasive species, have pointed to deficiencies in this area. The world needs a deeper stock of epidemiologists with a good sense of behavioral modeling and other economic principles as well as economists strong in the natural sciences. With budget funding of about $\$ 2$ million per year, the USDA Program of Research on the Economics of Invasive Species Management (PREISM) has focused attention on fostering interest, skill development, and insights in the area. Perhaps a joint PhD program at a school of public health could be partly funded by or integrated with the Centers for Disease Control and Prevention.

11. Prepare for a major crop failure. While U.S. corn yield variability appears to have declined in recent years, national corn production can fluctuate by $25 \%$ or more year-onyear with drought or floods. ${ }^{38} \mathrm{~A}$ natural event or biosecurity attack that had a significant effect on crop supplies is more likely to seriously disrupt food and animal feed markets than was the case in the recent past. This is because newly installed ethanol production plants are likely to have price insensitive short-run demands for feedstock, and may outbid livestock producers for scarce corn.

\section{REFERENCES}

1. Robbins L. An Essay on the Nature and Significance of Economic Science. 3rd ed. London: Macmillan; 1935.

2. Franco C, Deitch S. 2007. Billions for biodefense: federal agency biodefense funding, FY2007-FY2008. Biosecur Bioterror 2007;5(2):117-133.

3. Chalk P. Hitting America's Soft Underbelly: The Potential Threat of Deliberate Biological Attacks Against the U.S. Agricultural and Food Industry. Santa Monica, CA: RAND National Defense Research Institute; 2004.

4. Kimball AM. Risky Trade. Aldershot, UK: Ashgate; 2006.

5. Crutchley TM, Rodgers JB, Whiteside HP Jr, Vanier M, Terndrup TE. 2007. Agroterrorism: where are we in the ongoing war on terrorism? J Food Prot 2007;70(3):791-804.

6. Forest JJF. Homeland Security: Protecting America's Targets. Vol. 3. Westport, CT: Praeger Security International; 2006.

7. Indicators. Amber Waves 2007; 5(4):38. http://www.ers. usda.gov/AmberWaves/September07/PDF/Indicators.pdf. Accessed January 14, 2008.

8. National Agricultural Statistics Service. Agricultural Statistics, 2005. Washington, DC: National Agricultural Statistics Service; 2005. http://www.nass.usda.gov/Data_and_Statistics/ index.asp. Accessed January 23, 2008.

9. Fletcher J, Bender C, Budowle B, et al. Plant pathogen forensics: capabilities, needs, and recommendations. Microbiol Mol Biol Rev 2006;70(June):450-471.

10. Monke J. Agroterrorism: Threats and Preparedness. Washington, DC: Congressional Research Service Report for Congress; March 12, 2007. 
11. Huang S. Taiwan's hog industry-3 years after disease outbreak. Agricultural Outlook [U.S. Department of Agriculture] Oct 2000:20-23.

12. Thompson D, Muriel P, Russell D, et al. Economic costs of the foot and mouth disease outbreak in the United Kingdom in 2001. Rev Sci Tech 2002;21(3):675-687.

13. Blake A, Sinclair MT, Sugiyarto G. Quantifying the impact of foot and mouth disease on tourism and the UK economy. Tourism Economics 2003;9(Dec):449-465.

14. Breeze R. Agroterrorism: betting far more than the farm. Biosecur Bioterror 2004;2(4):251-264.

15. Blayney DP, Dyck J, Harvey D. Economic effects of animal diseases linked to trade dependency. Amber Waves April 2006:23-29.

16. Varian HR. Microeconomic Analysis. 3rd ed. New York: W.W. Norton; 1992.

17. Rushton J, Upton M. Investment in preventing and preparing for biological emergencies and disasters: social and economic costs of disasters versus costs of surveillance and response preparation. Rev Sci Tech 2006;25(1):375-388.

18. National Agricultural Statistics Service. Census of Agriculture, 2002. Washington, DC: National Agricultural Statistics Service; 2002.

19. Duffy M, Edwards W, Smith D, Reutzel J. 2003. Survey of Iowa Farm Leasing Practices. Iowa State University Extension Bulletin FM-1811. Ames: Iowa State University; December 2003. http:/www.extension.iastate.edu/Publications/FM1811. pdf. Accessed January 14, 2008.

20. Kroschewski K, Kramer M, Micklich A, Staubach C, Carmanns R, Conraths FJ. Animal disease outbreak control: the use of crisis management tools. Rev Sci Tech 2006;25(1):211-221.

21. National Research Council of the National Academies. Animal Health at the Crossroads: Preventing, Detecting, and Diagnosing Animal Diseases. Washington, DC: National Academies Press; 2005.

22. Calvin L. Responses to U.S. Foodborne Illness Outbreaks Associated with Imported Produce. Washington, DC: U.S. Department of Agriculture, Economic Research Service; February 2004.

23. Thaler RH. The Winner's Curse: Paradoxes and Anomalies of Economic Life. Princeton, NJ: Princeton University Press; 1993.

24. Hennessy DA, Roosen J, Jensen HH. Infectious disease, productivity, and scale in open and closed animal production systems. Am J Agri Econ 2005;87(Nov):900-917.

25. Short SD. Characteristics and Production Costs of U.S. Dairy Operations. Statistical Bulletin 974-6. Washington, DC: U.S. Department of Agriculture; February 2004.

26. U.S. Department of Agriculture, Economic Research Service. Agricultural Resource Management Survey (ARMS). www.ers. usda.gov/Briefing/ARMS/. Accessed March 6, 2008.

27. Greene C. 2007. Data track the expansion of international and U.S. organic farming. Amber Waves Sept 2007;5(4):36-37.

28. Steinfeld H, Wassenaar T, Jutzi S. Livestock production systems in developing countries: status, drivers, trends. Rev Sci Tech 2006;25(2):505-516.
29. Stokstad E. Plant pathologists gear up for battle with dread fungus. Science 2004;306(3 Dec):1672-1673.

30. Pan Z, Yang XB, Pivonia S, Xue L, Pasken R. Long-term prediction of soybean rust entry into the continental United States. Plant Dis 2006;90(7):840-846.

31. U.S. Department of Agriculture. Strategic Plan to Minimize the Impact of the Introduction and Establishment of Soybean Rust on Soybean Production in the United States. Washington, DC: Animal and Plant Health Inspection Service; November 2004.

32. U.S. Department of Agriculture. A Coordinated Framework for Soybean Rust Surveillance, Reporting, Prediction, Management and Outreach. Washington, DC: Animal and Plant Health Inspection Service; 2005. http://www.aphis.usda.gov/ plant_health/plant_pest_info/soybean_rust/downloads/ coordfram 041405.pdf. Accessed January 14, 2008.

33. Lorentzen A. Gov't probes Asian soybean rust in Iowa. Associated Press May 23, 2007. http://www.newsvine.com/_news/ 2007/05/23/734617-govt-probes-asian-soybean-rust-iniowa. Accessed January 14, 2008.

34. National Research Council of the National Academies. Countering Agricultural Bioterrorism. Washington, DC: National Academies Press; 2003.

35. Gottwald TR, Graham JH, Schubert TS. Citrus canker: the pathogen and its impact. Plant Health Progress 2002; doi:10.1094/PHP-2002-0812-01-RV. http://www.apsnet.org/ online/feature/citruscanker/. Accessed January 14, 2008.

36. Delgado C, McKenzie P, de Haan C, McLeod A., RiviereCinnamond A, Narrod C. Enhancing Control of Highly Pathogenic Avian Influenza in Developing Countries through Compensation: Issues and Good Practice. Washington, DC: World Bank; 2006.

37. Mansley LM, Dunlop PJ, Whiteside SM, Smith RGH. Early dissemination of foot-and-mouth disease virus through sheep marketing in February 2001. Vet Rec 2003;153(July 12):4350 .

38. Kucharik CJ, Ramankutty N. 2005. Trends and variability in U.S. corn yields over the twentieth century. Earth Interactions 2005;9(Dec):1-29.

Manuscript received March 20, 2007;

accepted for publication December 6, 2007.

Address reprint requests to: David A. Hennessy, PhD Department of Economics College of Agriculture and Life Sciences Center for Agricultural and Rural Development 578C Heady Hall Iowa State University Ames, IA 50014

E-mail: hennessy@iastate.edu 
lowa State University does not discriminate on the basis of race, color, age, religion, national origin, sexual orientation, gender identity, genetic information, sex, marital status, disability, or status as a U.S. veteran. Inquiries can be directed to the Director of Equal Opportunity and Compliance, 3280 Beardshear Hall, (515) 294-7612. 